ELORE (ISSN 1456-3010), vol. 15 - 2/2008.

Julkaisija: Suomen Kansantietouden Tutkijain Seura ry.

[http://www.elore.fi/arkisto/2_08/sii2_08.pdf]

\title{
Ajankohtaista: \\ KANSATIEDE JA MURROSTEN TUTKIMUS. VARSINAIS-SUOMEN SAARISTO INFORMAATIOAJAN MURROKSESSA
}

Lectio praecursoria Turun yliopistossa 10.6.2008.

$\underline{\text { Katriina Siivonen }}$

\section{Murrokset ja PERINNE}

Murrokset, erityisesti teollinen murros, ovat olleet Turun yliopiston kansatieteessä erityisen huomion kohteena sekä tutkimuksessa että opetuksessa laitoksen perustamisesta lähtien. Ilmar Talve nosti teollisen murroksen esille kansatieteen tutkimuskohteena vuonna 1958 Turun yliopiston sosiologian laitoksen julkaisussa (Talve 1958). Samana vuonna perustettiin kansatieteen laitos Turun yliopistoon, esimiehenä toimi sosiologian professori Esko Aaltonen. Talve nimitettiin kansatieteen ensimmäiseksi professoriksi vuonna 1962. Hän painotti teollisen murroksen tutkimuksen merkitystä myös virkaanastujaisesitelmässään (Talve 1963).

Tähän painotukseen liittyi hänen perusteluissaan kaksi keskeistä tieteenalaa määrittävää tekijää. Ensinnä hän määritti kansan käsittämään koko kansaa, siis sen kaikkia sosiaalisia kerroksia. Toiseksi hän kirjoitti, että perinne on "jatkuva olotila, joka yhdistää entisen nykyaikaan ja jatkuu tulevaisuudessakin. Perinne kuuluu olennaisena osana itse inhimillisen kulttuurin perusluonteeseen ja on siis ihmisen olemassaolon yksi perusta". Perinne ei hänellä ole jokin tietyn historiallisen - siis esiteollisen - kehityskulun lopputulos, vaan jatkuvasti sosiaalisessa vuorovaikutuksessa elävä, mennyttä toistava ja uudistava kulttuurinen prosessi. (Talve 1963, 21-22.) Näitä määritelmiä pidän edelleen näissä pelkistetyissä muodoissaan hyvin kestävinä ja käyttökelpoisina.

Perinne välittyy ihmiseltä toiselle. Monesti se käsitetään sukupolvelta toiselle välittyväksi aineelliseksi ja aineettomaksi kulttuuriseksi ainekseksi. Nils-Arvid Bringéus näkee kuitenkin perinteen käsitteen laajemmin teoksessaan Människan som kulturvarelse vuodelta 1981. Hänellä se on myös kulttuurisessa prosessissa nuoremmilta vanhem- 


\section{KANSATIEDE JA MURROSTEN TUTKIMUS}

mille välittyviä kulttuuripiirteitä. Hän näkee, että perinteen välittymisen ketju voi olla myös hyvin lyhyt. Lisäksi perinne voi välittyä yhtä lailla ajassa diakronisesti kuin yhdessä aikatasossa synkronisestikin. (Bringéus 1981, 122-126.) Nähdäkseni nämä perinteen välittymisen piirteet ovat nykyaikaa analysoitaessa yhä tärkeämpiä.

Materiaalisen ihmistekoisen ja luonnon luoman ympäristön tarkasteleminen kulttuurin osana on kansatieteelle luonteenomaista. Matti ja Riitta Räsänen painottavat tätä kirjoittaessaan vuonna 1981, että kulttuuri - ja siis myös siinä muokkautuva ja elävä perinne - syntyy ihmisten, heidän kanssaihmistensä ja materiaalisen ympäristön välisessä dialektisessa prosessissa. (Räsänen \& Räsänen 1982.) Pidän myös tämän huomioon ottamista kulttuurin analysoinnissa oleellisena. Aineellinen maailma on jatkuvasti läsnä arjessamme, se vaikuttaa toimiimme ja ajatuksiimme ja me vaikutamme toimillamme ja ajatuksillamme aineelliseen maailmaan.

Perinteen käsitteensä mukaisesti Talve näkee kansankulttuurin laajassa ajallisessa tarkastelussaan jatkuvana muutosprosessina, jonka voi arjen elämänpiirteitä analysoimalla jakaa toisistaan poikkeaviin periodeihin. Niiden välillä on aina pitempi tai lyhyempi siirtymäkausi, siis murroskausi. Kiinnostavaa on huomata, että oleellista jokaisessa arjessa näkyvässä murroksessa on lisääntyvä tiedon, ihmisten ja tavaran liikkumisen määrä suhteessa aiempaan. Poliittiset ja hallinnolliset taitekohdat sen sijaan eivät näy tuottavan tällaisia murroksia kulttuurin arkiseen prosessiin. (Talve 1979, 278-318.) Tarkastelen nyt näitä arkeen vaikuttavia murroksia Varsinais-Suomen saariston näkökulmasta. Niillä on pitkänkin ajan takaa vaikutuksensa nykyhetken kulttuurisiin ilmentymiin alueella.

\section{Murrokset VARSINAIS-SuOMEn SAARIStossa}

1200-luvulle ajoittuva keskiajan murros vakiinnutti saaristoon, kuten muuallekin läntiseen Suomeen, katolisen kirkon ja Ruotsin kruunun hallinnon. Niiden vaikutuksesta kulttuuriset kontaktit laajenivat ja tihenivät huomattavasti entisestä, informaation määrä lisääntyi ja paikallinen arkinen elämä koki entiseen nähden monia muutoksia. (Talve 1979, 283-286; Hiekkanen 2002.)

Ruotsin vallan myötä alueelle asettui myös ruotsinkielistä väestöä lännestä. Pitkälti samoilla saaristoseuduilla asuu edelleen ruotsinkielistä väestöä. Toisaalla varsinaissuomalaisessa saaristossa elää puolestaan vanhastaan suomenkielistä väestöä. Alueen eteläosassa on nykyisin, ennen vuodenvaihteen 2008-2009 kuntien yhteenliittymiä, kahdeksan enemmistön kieleltään ruotsinkielistä saaristokuntaa tai -kaupunkia. Pohjoisosissa mantereen tuntumassa ja luoteessa on suomenkielisiä saaristokuntia yhteensä yhdeksän kappaletta. Niistä osa sijaitsee osittain mantereella. Idässä on lisäksi yksi suomenkielinen kunta, Särkisalo, jossa on suhteellisen suuri ruotsinkielinen vähemmistö. Kieliraja on pysynyt näillä sijoilla suhteellisen vakaana satoja vuosia meidän päiviimme asti. (Talve 1979, 283; Halinen 2002, 65; Jutikkala 1949, kartta 9; Suomen tilastollinen vuosikirja 2005, 92-94; Valtioneuvoston asetus saaristokunnista 2004.)(1) 


\section{KatRIINA SiIVOnen}

1500-luvulta 1700-luvun alkuun ajoittuvassa uuden ajan murroksessa ihmiset kokivat seuraavan merkittävän informaation lisäyksen. Kirkko uudistui uskonpuhdistuksen myötä. Koulutusjärjestelmät ja kirjapainotaito kehittyivät. Lukutaito vankistui kansan keskuudessa. Kontaktit, tiedon kulku ja ihmisten kulkemisen mahdollisuudet lisääntyivät. (Talve 1979, 288-294; Lehtonen 2002.) Saaristo oli merkittävää aluetta, koska meritiet olivat sinä aikana keskeiset tiedon, tavaran ja ihmisten kulkemisessa. 1600-luvulta lähtien valtiovalta kehitti uutuuksina ja sijoitti saaristoon kommunikaatiota helpottamaan luotsilaitoksen, majakoita sekä saariston halki kulkevan Turun ja Tukholman välisen postireitin. (Öhman 1994, 19-21; Masonen ym. 1990.)

1800-luvun lopulla alkoi uusi kontakteja, ihmisten liikkumista sekä tiedon kulkua ja määrää merkittävästi lisännyt ja muuttanut vaihe, teollinen murros (Talve 1979, 33-318; Kolbe \& Kervanto-Nevanlinna 2003). Se näkyy saaristossa vähittäisenä pyynnin ja maatalouden vähenemisenä sekä väestön poismuuttona. Alueella on jonkin verran osin 1600-luvulta lähtien kehitettyä teollisuutta, mutta siitä huolimatta esihistorialliselta ajalta periytyvät primäärielinkeinot säilyttivät siellä suhteellisen tärkeän aseman teollistuvanakin aikana. 1800-luvulla ja 1900-luvun alussa saaristossa vahva kalastus menestyi hyvin, mutta joutui vaikeuksiin muun muassa Venäjän markkinoiden sulkeuduttua Suomen itsenäistyttyä. (Andersson 1997, 26-28; Andersson1998; Lukala1986, 228-232.) Kulkuyhteyksien kannalta saaristo muuttui teollisen murroksen myötä vähitellen entisestä keskeisten merenkulun ja meriteiden hallitsijasta uusien kehittyvien maakulkuyhteyksien kannalta periferiaksi (vrt. Taxell 1989).

Saman murroksen aikana rakennettiin kansallisvaltiota kansallisuusaatteen innoittamana. Sen ohessa luotiin Svenskfinland ja suomenruotsalaisuuden käsite. Saaristo ja Varsinais-Suomesta Turunmaa sen osana nousivat uuden suomenruotsalaisuuden idean symboleiksi. (Lönnqvist 2001, 26-30.) Ruotsalainen kansanpuolue otti Suomessa huolekseen teollisen ajan maaseudulle tuomat ongelmat nimenomaan saariston osalta. 1900-luvun alkupuoliskon kielikiistat suomen ja ruotsin kielten välillä vaikeuttivat tätä työtä, mutta niiden liennyttyä toisen maailmansodan jälkeen saaristopolitiikan harjoittaminen kävi helpommaksi. 1960-luvulla siihen otettiin mukaan myös suomenkielinen sisämaan järvialueiden saaristo, mikä nosti saaristopolitiikan painoarvoa valtakunnan tasolla. Siitä huolimatta saariston ja saaristopolitiikan merkitys suomenruotsalaisten keskuudessa on edelleen vahva. (Andersson 1997.)

Parhaillaan elämme murroksessa, jonka katsotaan informaatiovirtojen, ihmisten liikkuvuuden ja kontaktien märän voimakkaan lisääntymisen kautta johtavan verkostoyhteiskuntaan. Sille pidetään ominaisena yksilöllisten ja heterogeenisten kulttuuristen piirteiden korostumista, talouden ja yhteiskunnan dematerialisoitumista, kulttuuristen symbolien ja tarinoiden määrän ja merkityksen vahvistumista sekä paikallisista globaaleihin kontakteihin tihentyviä verkostoja. (Castells 1996; Castells 1998, 336-360; Wilenius 2004, 22-29.)

Saaristossa paikallisten erityispiirteiden ja niihin liittyen matkailun merkityksen odotetaan kasvavan kansallisella ja kansainvälisellä tasolla. Saaristosta löytyy kummaltakin kielialueelta otollista eksoottista mennyttä symboleiksi, joita halutaan tuotteistaa esimerkiksi matkailumarkkinoille. Saaristossa asuvien ihmisten toimissa ja muistissa, ja osin myös alueen elinkeinorakenteessa, on säilynyt riittävästi piirteitä 


\section{KANSATIEDE JA MURROSTEN TUTKIMUS}

monet kulttuuriset murrokset kestäneistä primäärielinkeinoista ja alueella harjoitetusta merenkulusta sekä niihin liittyvästä elämäntavasta.

\section{NYKYMURROKSEN TUTKIMINEN}

Myös Euroopan unioni ohjaa käyttämään alueiden kehittämisessä paikallista kulttuurista omintakeisuutta, jotta siitä saataisiin tulevaisuudessa kasvavaa hyvinvointia, elinvoimaa ja taloudellista tuottoa muun muassa tälle nykymurroksessa elävälle seudulle (Shore 2000, 42-54). Euroopan unioniin integroitu suomalainen, tulevaisuutta rakentava aluekehitystyö antaa entistä enemmän valtaa alueilla toimiville aluekehityksen organisaatioille. Samalla se pistää nämä organisaatiot ja niiden edustamat alueet keskinäiseen kilpailuun jakamastaan aluekehityksen merkittävästä taloudellisesta tuesta. Globaalin talouden ohjaamana alueet asettuvat keskinäiseen kilpailuun myös, kun ne houkuttelevat uusia asukkaita, yritystoimintaa - muun muassa matkailuyrityksiä - ja näille yrityksille asiakaskuntaa. Tässä koko prosessissa kulttuurinen omintakeisuus asetetaan kehitystyön ja kilpailun välineeksi. (Hautamäki 1999, 26-27.)

Tämä tilanne, kuten murroskausien tilanteet yleensäkin, on kulttuurisesti hyvin kiinnostava. Vaikka murrokset sinänsä ovatkin olleet kansatieteellisessä tutkimuksessa kiinnostuksen kohteena, ei tällä alalla Suomessa ole toistaiseksi vahvasti suunnattu nykymurroksen ja tulevaisuuteen orientoituvan toiminnan analyysiin. Se on kuitenkin syytä tehdä. Ilman kulttuurin tutkimuksen tuomaa ymmärrystä nykymurroksen ilmentymistä yhteiskuntamme toimijoilta jää paljon sekä kulttuurisiin, että myös taloudellisiin, poliittisiin ja hallinnollisiin prosesseihin vaikuttavista seikoista hahmottamatta. Tämän tarpeen tuomaan haasteeseen olen tarttunut väitöskirjatyössäni.

Kuten sanottu, ihmiset välittävät perinnettä toisilleen kulttuurisessa prosessissa jatkuvassa vuorovaikutuksessa sosiaalisen ja aineellisen ympäristönsä kanssa. Samalla he muokkaavat perinnettä ja luovat siihen uusia piirteitä. Väitöskirjani kulttuuriteorian lähtökohtana ovat yhtäältä yksittäiset ihmiset, toisaalta heidän sosiaalinen ja aineellinen ympäristönsä ja kolmanneksi merkitykset, jotka kaikki muuntuvat ja muokkautuvat tässä vuorovaikutusprosessissa. Tämä kokonaisuus, ihmiset, ympäristö ja merkitykset, tarvitaan kulttuurin jäsentämiseksi maailmassa, jossa informaation määrä lisääntyy nykyiseen tapaan ja ihmisten välisessä vuorovaikutuksessa tietoisina ilmennettyjen symbolien painoarvo kasvaa. Muokkaamani ja soveltamani teoria rakentuu pääosin Fredrik Barthin (mm. Barth 1994) ja Ulf Hannerzin (1992) sosiaaliantropologisten näkemysten ja Charles S. Peircen semiotiikan varaan.

Suomi liittyi Euroopan unioniin vuoden 1995 alussa. Suomen- ja ruotsinkielisten asema ja yhteistoiminta nousivat Varsinais-Suomen saaristossa silloin voimakkaasti puheeksi erityisesti Euroopan unioniin integroidussa aluekehitystyössä toimivien keskuudessa. Lisäksi paikallisen kulttuurin omintakeiseksi katsottuja piirteitä otettiin aluekehityksessä käyttöön. Nämä havainnot johtivat minut kysymään, mitä identiteetit ja alueellisuus ovat ihmisten arjessa, mitä ne ovat aluekehitystyössä ja miten nämä kaksi osin erilaisiksi osoittautunutta maailmaa kohtaavat. 


\section{KatRIINA SiIVOnen}

\section{SAARISTON MÄÄRITTYMINEN ARJESSA JA ALUEKEHITYSTYÖSSÄ}

Varsinais-Suomen saaristossa arjen käytänteissä on olemassa lukuisia erilaisia tapoja hahmottaa ensinnä itse saaristo ja sen rajat ja toiseksi omaksi koettu saaristoalue. Laajimmillaankin saaristosta putoavat pois suuret, mantereen läheiset saaret. Kaikkiaan saaristo määrittyy jatkumoksi, joka laajimmillaan kattaa lähes kaikki merialueen saaret. Tiukimmillaan todellista saaristoa ovat vain uloimmat saaret, jonne kulkeminen on oman veneen varassa tai ehkä yhteysalus- tai lossimatkan takana ja jossa asuu ympärivuotisia saaristolaisia, joilla on siellä sukujuuret ja jotka kykenevät selviämään sen vaativassa ympäristössä. Ulkosaaristo kaikkiaan näiden kriteerien mukaan on symbolisesti oikeampaa saaristoa kuin sisäsaaristo. Tämän jatkumon sisälle mahtuu lukuisia erilaisia saariston rajauksia. Ne voivat yhdelläkin henkilöllä vaihdella tilanteen mukaan. Käsitykset ovat pienessä muutoksessa koko ajan, mutta erityisesti esimerkiksi siltojen rakentamiset tai lossilinjojen avaamiset tuovat tullessaan muutoksia myös todellisena pidetyn saariston määrittymiseen.

Pääasiassa oma saaristo hahmottui arjessa käytänteiden tuomana tuttuutena alueilla, joilla on tapana liikkua, ja sen ulkopuolisten alueiden vierautena. Vieraana alueena saattoivat olla myös toista kieltä enemmistön kieleltään edustavat saaristoseudut. Silloin oma alue ei määrity tietoisen symbolisena vaan tuttujen toiminnallisten käytänteiden kautta. Omankielinen alue on tuttu, toisesta ei juuri mitään tiedetä. Ulkosaariston lisäksi kuitenkin kieliraja oli esillä myös selkeästi ilmaistuna symbolina, joko joissakin yhteyksissä omaa aluetta rajaavana tekijänä tai usein sen sijaan omaan alueeseen kuuluvana ja sitä luonnehtivana ilmiönä. Jälkimmäisessä tapauksessa omaksi koettu saaristo oli kaksikielinen ja kieliraja oli yksi sen omaksi koettu ominaispiirre.

Institutionaalisesti saaristoa on 1900-luvun alkupuolelta teollisesta ja kansallisesta murroksesta lähtien määrittänyt suomenruotsalaisuus. Siten saaristo on symbolisella tasolla ollut ruotsinkielinen, vaikka siellä on arkea eletty ruotsinkielisiin alueisiin verrattuna hyvin samanlaisissa oloissa ja samanlaisin muodoin myös suomeksi suomenkielisissä saaristokunnissa. 1900-luvulla ruotsinkielinen toiminta on hallinnut saaristopolitiikkaa ja alueella harjoitettua aluepolitiikkaa. Kielipolitiikkaa on toteutettu saaristopolitiikan keinoin, mikä ei kuitenkaan ole ollut esillä kaikille avoimina symboleina. Saaristo ruotsinkielisten symbolina on tavanomaistunut hallinnollisiin ja poliittisiin käytänteisiin hiljaiseksi ja sitkeästi itseään toistavaksi tiedoksi, joka ohjaa vahvasti alueen kehittäjien toimia mutta ei nouse tietoiseen keskusteluun. Tällaiset tavanomaistuneet symbolit ovat siten hyvin kestäviä.

Suomenkieliselle saaristolle tuli uuden, Euroopan unioniin integroidun aluekehitystyön myötä entistä suurempi tarve esiintyä saaristona myös symbolisessa mielessä, ei vain arjen käytänteissä. Omintakeista saaristokulttuuria esille tuomalla oli mahdollisuus päästä osalliseksi entiseen verrattuna suuremmista Euroopan unionin ja kansallisten lähteiden jakamista aluekehitystyön rahoista. Samalla kuitenkin hallinnon ja politiikan käytänteiksi tavanomaistunutta saariston symbolista ruotsinkielistä luonnetta ja yhteistyön rakenteita oli hankala muuttaa. Tämä näkyi ajoittain esille pulpahtavina kiistoina eri kieliryhmien asemasta aluekehityksen toimissa. Kielikysymys ei ollut 


\section{KANSATIEDE JA MURROSTEN TUTKIMUS}

Euroopan unioniin integroitumisen yhteydessä saaristossa keskusteluttava aihe arjen kulttuurissa, vaan nimenomaan aluekehityksen organisaatioiden toimissa.

Uudenlaisena yhteenliittymänä 2000-luvun saaristossa on eurooppalainen European Small Islands Federation. Siinä ovat mukana jotkin eurooppalaiset valtiot saaristoalueineen. Varsinais-Suomesta siinä kuitenkin aktiivisina näyttäytyvät nimenomaan ulkosaariston edustajat kielirajan yli. Tässä organisoituneessa toiminnassa arjen symbolisesti vahva ulkosaaristo näyttää vahvemmalta kuin tähän asti organisaatioiden kentässä oleellinen saariston symbolinen ruotsinkielisyys ja vähittäin vahventunut saariston symbolinen suomenkielisyys. Näin siis kansainvälinen verkosto näyttäisi muuttavan saariston symbolisten merkitysten painotuksia siitä, mitä ne viime vuosikymmeninä Suomessa ovat olleet.

\section{SAARISTOIDENTITEETTIEN SISÄLLÖISTÄ}

Arkisessa kulttuurissa saaristossa elävät ihmiset sitoutuvat kaikkein voimakkaimmin omaksi kokemalleen saaristoalueelle sen luonnon kautta. Kaikkiaan saaristoon identifioituminen koostuu kokemuksellisesta ja toiminnallisesta luontoa ja yhteisön käytänteitä kuvaavista merkeistä. Ne toimivat hiljaisena tietona, jota on välillä vaikea tavoittaa ja kuvailla sanallisesti. Joissakin yhteyksissä nämä merkit nousevat tietoiselle tasolle symboleiksi. Tällaisia ovat samanaikaisesti kaunis ja hurja saaristoluonto, saarten rantojen rajat, vapaus tehdä töitä ja määrittää omaa elämisen tapaa näiden rajojen sisällä sekä saarilla opitut tiedot ja taidot, jotka päihittävät symbolisesti ulkopuolisen viranomais- ja kirjaviisauden. Kulttuuri ja identiteetit ovat jatkuvasti pienessä dynaamisessa liikkeessä, myös saaristossa. Saaristoidentiteeteissä hyvin vallitsevana piirteenä on kuitenkin se, että muutokset halutaan määrittää itse saarten symbolisten rajojen sisällä. Luonto hyväksytään vahvaksi toiminnan ja identifioitumisen määrittäjäksi. Vaikutteita kaikkiaan silti saadaan ja annetaan hyvin moninaisesti sekä aivan paikallisesti että laajemmissa verkostoissa kansainvälisiin asti.

Aluekehitystyön organisaatioissa toimivista monet asuvat saaristossa. He elävät, aistivat, havainnoivat ja toimivat siten osana sen arkista kulttuurista prosessia. He toteuttavat kuitenkin myös toimissaan aluekehitystyön organisaatioiden tavoitteita. Nämä tavoitteet ovat osittain tavanomaistuneet merkeiksi, jotka eivät ole tietoisina heillä mielessään. Ne ovat saattaneet myös välittyä heille organisaatioissa hiljaisena tietona ilman, että ne ovat tulleet heille tietoisiksi. Osittain ne saatetaan myös pitää hiljaisena tietona. Jotkin Svenskfinlandin symbolista saaristoa ylläpitävistä käytänteistä olivat tällaisia.

Toisinaan organisaatioiden toimet olivat taas hyvin selkeästi ilmaistuja. Ne asettuivat tietoiseen jännitteeseen saariston arkisen kulttuurisen prosessin kanssa tavoitteenaan tuoda siihen muutoksia. Osin ne nostivat arkisissa saaristoidentiteeteissä oleellisia piirteitä esille. Tällaisia olivat entisajan saaristoelämän ja niihin pohjautuvien saaristotaitojen arvostus. Niillä oli hyvin suuri merkitys paikallisille ihmisille, vaikkakaan he eivät halunneet, että saariston kehittämisessä rajoitutaan vain menneen ajan elämänmuodon säilyttämiseen ja vaalimiseen. 


\section{KatRiIna SiIvonen}

Osin kehittämishankkeiden tavoitteet toimivat tietoisella tasolla paikallisia saaristoidentiteettejä vastaan. Näin tapahtui esimerkiksi silloin, kun kehitettiin koulutusta saaristoalueella tai kun alueelle luotiin uusia yhteistyöverkostoja. Silloin asetuttiin toimimaan saaristoidentiteetissä monille oleellisten ulkopuolisia auktoriteetteja kaihtavan itsemääräämisoikeuden ja sosiaalisen tasapainon tavoittelun piiriin. Tätä kautta uusia käytänteitä ja yhteistyösuhteita kuitenkin syntyi, jos toiminta onnistuttiin sovittamaan riittävästi saaristoidentiteettien keskeisten piirteiden mukaiseksi.

Osittain hankkeiden tuottamat saaristoa kuvaavat symbolit törmäsivät tiedostamattaan saaristoidentiteeteissä oleellisten piirteiden kanssa. Silloin hankkeissa koostettiin imago osin paikallisille identiteeteille vieraista elementeistä. Tätä tehtiin myös ulkopuolisten auktoriteettien avulla, mikä jo sinänsä asettuu ristiriitaan monien saaristoidentiteettien kanssa. Tästä syntyi sanaton kokemus saariston myymisestä.

\section{KULTTUURISESTI KESTÄVÄ ALUEKEHITYSTYÖ}

Kaikkiaan on Euroopan unionin kulttuuri- ja aluepolitiikan tavoitteiden mukaista tuottaa uusia, alueellisuutta tukevia identiteettejä, joiden nähdään luovan alueille uusia taloudellisen toiminnan edellytyksiä nykyisessä globaalissa murroksessa. Euroopan unionin kulttuuri- ja aluepolitiikka kannustaa tällaiseen toimintaan ilman, että siinä otetaan tavoitteeksi vuorovaikutteista suhdetta eri alueilla elävien identiteettien ilmausten kanssa arkisen elämän toiminnallisella tasolla. EU-politiikka ei kuitenkaan myöskään estä tällaista toimintaa, jos sitä hankkeissa huomataan toteuttaa ja se muuten noudattaa EU-politiikan tavoitteita.

Jotta tämä kokonaisuus aukeaisi analyysissa, on oleellista tarkastella aluekehitystyötä hankkeineen ja organisaatioineen kulttuurin osana, ei vain toimijoina, jotka käyttävät ja kehittävät kulttuuria. Identiteeteillä ja identifikaation prosesseilla on merkitystä sekä yksittäisten, arjessaan elävien ihmisten, että aluekehityksen organisaatioiden näkökulmasta. Nämä ovat väistämättä vuorovaikutuksessa keskenään.

Kulttuurisesti kestävä aluekehitystyö ottaa nämä eri tasoilla toimivat kulttuuriset prosessit toimissaan huomioon. Se tulee tehdä sekä kulttuurin sanattomaksi tavanomaistuneissa, että sen selkeästi symbolisina ilmaistuissa muodoissa. Kulttuurisesti kestävän aluekehitystyön toisena periaatteena on se, että alueiden kulttuurisessa määrittelyssä aluekehitystyön organisaatioissa tulee ottaa huomioon myös muut kuin organisaation omat kohdealueet tai -ihmisryhmät. Millään niistä ei ole oikeutta omia itselleen sellaisia kulttuuripiirteitä, joita myös toisaalla esiintyy. Myöskään millään aluekehitystyötä tekevällä taholla ei ole oikeutta yksinomaiseen kulttuuriseen määrittelyvaltaan.

Arkisessa kulttuurissa ja alueellisessa kehittämistyössä on kummassakin paikallisten identiteettien kiinnikkeinä omanlaistaan hiljaista tietoa ja julki tuotuja keskeisiä symboleja. Tarvitaan tietoa ja ymmärrystä sekä niiden kummankin kulttuurisista ominaispiirteistä että niiden välisistä suhteista, jotta alueita voisi murroksen pyörteissä kehittää kulttuurisesti kestävästi. 


\section{KANSATIEDE JA MURROSTEN TUTKIMUS}

\section{VIITTEET}

1. Saaristolakiin perustuvan valtioneuvoston saaristokuntia koskevan asetuksen mukaan Turun, Naantalin ja Kaarinan kaupunkien saaret eivät kuulu saaristoon. Olen rajannut työssäni saariston lähtökohtaisesti tämän hallinnollisen rajauksen mukaisesti, mutta nostan analyysissani esille kuitenkin erilaisia siitä poikkeavia saariston rajauksia empiirisen aineiston pohjalta.

\section{KiRjallisuUs}

ANDERSSON, KJELL 1997: Den finländska skärgårdspolitikens framväxt och utveckling. Strukturell bakgrund, aktörer och institutioner. Helsingfors: Forskningsinstitutet, Svenska social- och kommunalhögskolan vid Helsingfors universitet.

- 1998: Näringsutveckling i sydvästra Finlands skärgård. Tolv kommuner i ljuset av offentlig statistik. Helsingfors: Svenska social- och kommunalhögskolan vid Helsingfors universitet.

BARTH, FREDRIK 1994: Nye og evige temaer i studiet av etnisitet. - Fredrik Barth, Manifestasjon og prosess. Oslo: Universitetsforlaget.

BRINGÉUS, NILS-ARVID 1981: Människan som kulturvarelse. Lund: LiberLäromedel.

CASTELLS, MANUEL 1996: The Information Age. Economy, Society and Culture. Volume I. The Rise of the Network Society. Cambridge: Blackwell Publishers.

- 1998: The Information Age. Economy, Society and Culture. Volume III. End of Millenium. Cambridge: Blackwell Publishers.

HALINEN, PETRI 2002: Suomi esihistorian ja historian taitteessa. - Lehtonen, Tuomas M. S. \& Joutsivuo, Timo (toim.), Suomen kulttuuribistoria 1, Taivas ja maa. Helsinki: Kustannusosakeyhtiö Tammi.

HANNERZ, ULF 1992: Cultural Complexity. Studies in the Social Organization of Meaning. New York: Columbia University Press.

HAUTAMÄKI, VELI-PEKKA 1999: Aluepolitiikan tavoitteet lainsäädännössä. - Kunnallistieteellinen aikakauskirja 1/1999.

HIEKKANEN, MARKUS 2002. Kristinuskon tulo Suomeen. - Lehtonen, Tuomas M. S. \& Joutsivuo, Timo (toim.), Suomen kulttuuribistoria 1, Taivas ja maa. Helsinki: Kustannusosakeyhtiö Tammi.

JUTIKKALA, EINO 1949: Suomen historian kartasto. Porvoo: WSOY.

KOLBE, LAURA \& KERVANTO NEVANLINNA, ANJA 2003. Eurooppalainen Suomi. - Kervanto Nevanlinna, Anja \& Kolbe, Laura (toim.), Suomen kulttuuribistoria 3, Oma maa ja maailma. Helsinki: Kustannusosakeyhtiö Tammi.

LEHTONEN, TUOMAS M. S. 2002: Reformaatio. - Lehtonen, Tuomas M. S. \& Joutsivuo, Timo (toim.), Suomen kulttuurihistoria 1, Taivas ja maa. Helsinki: Kustannusosakeyhtiö Tammi.

LUKALA, MARIANNE 1986: Dalsbruk 1686-1986. Dalsbruk: Ovako. 


\section{KatRIInA SIIVONEN}

LÖNNQVIST, BO 2001: Myten om den finlandssvenska familjen. - Åström, AnnaMaria \& Lönnqvist, Bo \& Lindqvist, Yrsa, Gränsfolkets barn. Finlandssvensk marginalitet och självhävdelse $i$ kulturanalytisk, perspektiv. Helsingfors: Svenska litteratursällskapet i Finland.

MASONEN, JAAKKI \& HAKKARAINEN, MIKA \& LEHTONEN, ANIT'TA \& SALMINEN, TAPIO 1990: Suuri Postitie Varsinais-Suomessa. Tien linjaus, ajoitus ja nykyinen käyttö. Turku: Varsinais-Suomen seutukaavaliitto.

RÄSÄNEN, MATTTI \& RÄSÄNEN, RIITTA 1982: Ihminen fyysisen ympäristön viitekehyksessä. - Suojanen, Päivikki \& Saressalo, Lassi (toim.), Kulttuurin kenttätutkimus. Tampere: Tampereen yliopiston kansanperinteen laitos.

SHORE, CHRIS 2000: Building Europe. The Cultural Politics of European Integration. London \& New York: Routledge.

Suomen tilastollinen vuosikirja 2005. Helsinki: Tilastokeskus.

TALVE, ILMAR 1958: Kansatiede ja murroskausi. Työväestön, eri ammattien ja kaupunkikulttuurin tutkimisesta. - Turku University, Institute of Sociology, Suomi - Finland, N:o 4.

- 1963: Suomalainen kansatiede. Tähänastista kehitystä ja tulevaisunden tehtäviä. Turku: Turun yliopisto, kansatiede.

- 1979: Suomen kansankulttuuri. Historiallisia päälinjoja. Helsinki: Suomalaisen Kirjallisuuden Seura.

TAXELL, CHRISTOFFER 1989: Samhällsutvecklingen och skärgården. - "Kontakt och konflikt i skärgården". Nordisket symposium om skärgårdsfrägor 20.-21.9.1986, Hanaholmens Kulturcentrum för Sverige och Finland, Esbo, Finland. Helsingfors: Nordeskiöld-samfundet i Finland r.f.

Valtioneuvoston asetus saaristokunnista ja muiden kuntien saaristo-osista, joibin sovelletaan saaristokuntaa koskevia säännöksiä 21.12.2004/1211.

WILENIUS, MARKKU 2004: Luovaan talouteen. Kulttuuriosaaminen tulevaisunden voimavarana. Helsinki: Edita.

ÖHMAN, MARTIN 1994: Utö, elämää meren ebdoilla. Helsinki: Metsähallitus, Saaristomeren puistoryhmä.

Katriina Siivonen 2008: Saaristoidentiteetit merkkien virtoina. Varsinaissuomalainen arki ja aluekehitystyö globalisaation murroksessa. Kansatieteellinen Arkisto 51. Helsinki: Suomen Muinaismuistoyhdistys.

Filosofian tohtori Katriina Siivonen on toiminut tutkijana ja projektipäällikkönä Turun kauppakorkeakoulussa Tulevaisuuden tutkimuskeskuksessa vuodesta 2002 lähtien. Väitöskirjan hän on tehnyt Turun yliopistoon kansatieteeseen, missä hän on toiminut ma assistenttina 1997-1998, tutkijakoulutettavana Kulttuurisen vuorovaikutuksen ja integraation tutkijakoulussa 1999-2000 ja apurahatutkijana useina eri ajanjaksoina, osin Tulevaisuuden tutkimuskeskuksessa työskentelyn lomassa. 